\title{
Determination of Human Linear IgE Epitopes of Japanese Cedar Allergen Cry j 1
}

\author{
Kayoko Takagi, Reiko Teshima,* and Jun-ichi SaWAda \\ Division of Biochemistry and Immunochemistry, National Institute of Health Sciences; 1-18-1 Kamiyoga, Setagaya-ku, \\ Tokyo 158-8501, Japan. Received December 3, 2004; accepted May 19, 2005; published online May 25, 2005
}

Cry $\mathbf{j} 1$ is one of the major allergens in Japanese cedar pollen. We attempt high throughput analysis and comprehensive identification of the linear IgE epitopes of Cry $\mathbf{j} 1$. A series of overlapping synthetic Cry $\mathbf{j} 1$ peptides chemically spotted on cellulose membrane was probed with sera from patients in Japan and United States, which were reactive to $\mathrm{Cry} \mathbf{j} \mathbf{1}$, and the reactivity of one of the detected sequences was confirmed by means of competitive ELISA using peptide as coated antigen. The peptide ${ }^{331}$ NGNATPQLTKNA ${ }^{342}$ (peptide 166) was detected by all three pooled sera used, and peptide ${ }^{103}$ NGGPCVFIKRVS ${ }^{114}$ (peptide 52) was detected by two of the three pools of sera. In addition, several peptides reacted with one of the pooled sera. IgE binding to peptide 166coated wells was inhibited by addition of peptide 166 for several individual patient sera, suggesting that peptide 166 is one of the linear epitopes of Cry $\mathbf{j} \mathbf{1}$. Since patients in United States were suggested to be rarely sensitized with Japanese cedar, they were sensitized with the similar tree pollen allergens such as Cup s 1 and Jun a 1, and cross-reacted with Cry $\mathbf{j} 1$. We have comprehensively investigated human IgE epitopes of $\mathrm{Cry} \mathbf{j} 1$ and succeeded in identifying a common linear epitope, ${ }^{331}$ NGNATPQLTKNA ${ }^{342}$.

Key words Cry j 1; Japanese cedar (Cryptomeria japonica); IgE epitope; linear; spot; overlapping peptide

Japanese cedar (Cryptomeria japonica) pollen is spread over most areas of Japan in early spring and causes pollinosis, which is now a serious social problem. Cry $\mathrm{j} 1$ is one of the major immunoglobulin E (IgE)-binding allergens in Japanese cedar pollen. ${ }^{1,2)}$ It consists of 353 amino acids and four different saccharide chains, and 2-D immunoblotting with patients' sera has identified at least 12 IgE-binding isoforms of $41-46 \mathrm{kDa}^{3}$ )

The core sequence of a mouse B-cell epitope was found to be ${ }^{145} \mathrm{VHPQDGDA}^{152}$, but the peptide does not inhibit human IgE binding to Cry $\mathrm{j} 1{ }^{4}{ }^{4}$ Based on the inhibition of human IgE binding to Cry $\mathrm{j} 1$ by murine monoclonal antibodies, the presence of five independent epitopes was suggested. ${ }^{5,6)}$ IgE-binding sites on pollen allergens are generally reported to be conformational. ${ }^{7,8)}$ Taniai et al. reported that the inhibitoriest monoclonal antibody ( $\mathrm{mAb} 046)$ recognized a conformational epitope on Cry $\mathrm{j} 1$. On the other hand, human IgE reacted with the V8 protease-digested fragment NGNATPQLTKNAGVLTCSLSKR of Cry $\mathrm{j} 1$, of which the third residue Asn was glycosylated, ${ }^{9)}$ thus linear epitopes are possible to play a part of pollen allergy. Linear epitopes are likely to be stable for heating and detergent treatment and the epitope sequences are useful information to evaluate the cross-reactivity with other proteins.

In this study, we have comprehensively identified linear IgE (B-cell) epitopes of Cry $\mathrm{j} 1$ using synthetic overlapping peptides on cellulose membrane (SPOTs) ${ }^{10)}$ and sera from patients with cedar pollen allergy.

\section{MATERIALS AND METHODS}

Serum Specimens Nine commercially available sera (\#1 to \#9; Plasma Lab International, Everett, WA, U.S.A.) and 21 Japanese patients' sera (\#10 to \#30) those reacted positively with Cry j 1 in enzyme-linked immunosorbent assay for $\operatorname{IgE}$ (IgE-ELISA), and sera from Cry j 1-negative 6 healthy volunteers (anti-Cry j 1 IgE-ELISA titers OD450-570<0.2) were also used. The patients' sera (\#1-\#30) were used sepa- rately or as 5 groups of pooled sera, and the characteristic of each patient's serum and the grouping were shown in Table 1. The obtained sera were not always enough volume for the experiments, so we produced serum pools by mixing sera from 3 or 10 patients according to each amounts.

Informed consent was obtained from all the patients and volunteers. This study was approved by the Institutional Review Board of the National Institute of Health Sciences.

SDS-PAGE and Immunoblotting Purified Cry j 1 (HBL-C-1, Hayashibara Biochemical Laboratories Inc., Okayama, Japan, $25 \mu \mathrm{g}$ ) was electrophoresed and transferred to a nitrocellulose membrane. The membrane was blocked, cut into $4 \mathrm{~mm}$ strips, and incubated at room temperature for 1 $\mathrm{h}$ with diluted human serum $(1: 10)$ and subsequently at $4{ }^{\circ} \mathrm{C}$ for $18 \mathrm{~h}$. After washing with $50 \mathrm{~mm}$ Tris-buffered saline, $\mathrm{pH}$ 8.0, containing $0.05 \%(\mathrm{v} / \mathrm{v})$ Tween 20 (TBS-T), the strips were incubated at room temperature for $2.5 \mathrm{~h}$ with horseradish-peroxidase (HRP)-conjugated goat anti-human $\operatorname{IgE}(\mathrm{Fc})$ (Nordic Immunology, Stockholm, Sweden; 1:500 dilution), and washed again. The bound IgE antibodies were detected with a Western Lightning Chemiluminescence Reagent (PerkinElmer Life Sciences, Inc., Boston, MA, U.S.A.) and visualized with an ECL mini-camera (RPN 2069; Amersham Biosciences Corp., Piscataway, NJ, U.S.A.).

Spot Assay The overlapping Cry j 1 (Swiss Prot accession no. P18632) peptide-synthesized membrane (SPOTs membrane) was prepared by Sigma Genosys (The Woodlands, TX, U.S.A.). Each peptide was twelve amino acids long and offset by 2 amino acids. After washing with methanol, the membrane was blocked overnight with buffer A [the blocking solution (SU-07-251, Sigma Genosys) diluted to $1: 10$ in TBS-T with $5 \%(\mathrm{w} / \mathrm{v})$ sucrose]. The membrane was then washed with TBS-T and incubated overnight at $4{ }^{\circ} \mathrm{C}$ with diluted pooled sera (1:5 in the buffer A). After washing, the membrane was incubated at room temperature for $3 \mathrm{~h}$ with HRP-conjugated goat anti-human $\operatorname{IgE}(\mathrm{Fc})$ ( $1: 500$ in the buffer $A)$ and washed again. The bound IgE antibodies were detected as described in "SDS-PAGE and 
immunoblotting" section. The SPOTs membrane was reused after a regeneration procedure according to the manufacturer's protocol.

Peptide ELISA and the Inhibition Assay Two 12-mer peptides 52 (NGGPCVFIKRVS) and 166 (NGNATPQLTKNA) were produced by SCRUM Inc. (Tokyo, Japan) with Fmoc/t-Boc strategy on solid phase and their purity was 98.4 and $92.0 \%$, respectively by HPLC. AquaBind micro plates (Asahi Techno Glass Co., Tokyo, Japan) were treated for $1 \mathrm{~h}$ at $37^{\circ} \mathrm{C}$ with 12 -mer peptides in binding buffer $(100 \mathrm{~mm}$ borate buffer, $\mathrm{pH} 9.6)$ at a concentration of $10 \mu \mathrm{g} /$ well. After washing with washing buffer $[\mathrm{pH} 7.2 ; 0.5 \mathrm{M}$ $\mathrm{NaCl}, 0.0026 \mathrm{M} \mathrm{KCl}, 0.0014 \mathrm{M} \mathrm{KH}_{2} \mathrm{PO}_{4}, 0.0082 \mathrm{M} \mathrm{Na}_{2} \mathrm{HPO}_{4}$, and $1 \%(\mathrm{v} / \mathrm{v})$ Triton X-100 (Sigma Chemical Co.)], each well was incubated for $18 \mathrm{~h}$ at $37^{\circ} \mathrm{C}$ with $200 \mu \mathrm{l}$ of blocking buffer [pH 9.6; 15\% (w/v) PEG8000 (Sigma Chemical Co.), $1 \%(\mathrm{w} / \mathrm{v})$ bovine serum albumin, and $1 \%(\mathrm{v} / \mathrm{v}) 2-$ aminoethanol in binding buffer]. Then the plates were washed and incubated overnight at $4{ }^{\circ} \mathrm{C}$ with serum diluted $1: 10$ in dilution buffer $[1 \%(\mathrm{w} / \mathrm{v})$ bovine serum albumin, $1 \%$ (w/v) dextran (molecular weight, 60000_90000; Wako Pure Chemical, Osaka, Japan), 20\% (v/v) fetal bovine serum in washing buffer]. It was washed again, incubated with HRPconjugated goat anti-human $\operatorname{IgE}(1: 1000$ in dilution buffer), washed, and added with colorimetric substrate solution (TMB reagent, \#555214, BD Biosciences, San Diego, CA, U.S.A.). After $15 \mathrm{~min}$, the reaction was stopped with $2 \mathrm{~N}-$ $\mathrm{H}_{2} \mathrm{SO}_{4}$, and absorbance (OD450-570) was measured. We judged the patients' sera as peptide-ELISA positive when the absorbance of the sera was greater than 2SD of the mean absorbance of three healthy donors' sera.

As for inhibition assay, each serum was pre-incubated with or without synthetic peptide [166 or unrelated (EKQKEK) peptide, $100 \mu \mathrm{M}$ ] at $4{ }^{\circ} \mathrm{C}$ overnight before applying in the blocked well.

\section{RESULTS AND DISCUSSION}

Immunoblotting with Serum IgE The reactivities of five pooled (G1 - G5) and an individual (\#30) sera with Cry j 1 were determined by immunoblotting (Fig. 1). The IgE antibodies in three pooled sera (G2, G3, and G4) clearly bound to denatured Cry j 1 antigen $(37-43 \mathrm{kDa})$. Though all the sera from patients highly reacted with Cry j 1 by ELISA (Table 1), the IgE antibodies in two groups of pooled sera (G1 and G5) and a \#30 serum were only weakly bound to denatured Cry $\mathrm{j} 1$. Thus they might recognize conformational epitopes of Cry $\mathrm{j} 1$.

Spot Assay The sera G2, G3, and G4 were used for spot assay. As shown in Fig. 2, all three pooled sera reacted strongly with peptide $166\left({ }^{331}\right.$ NGNATPQLTKNA $\left.{ }^{342}\right)$, and G3 and G4 reacted weakly with peptide $52\left({ }^{103} \mathrm{NGGPCV}\right.$ FIKRVS ${ }^{114}$ ). G3 reacted weakly with several other peptides, $23\left({ }^{45} \mathrm{NSDDDPVNPAPG}^{56}\right), 47\left({ }^{93} \mathrm{DGRGAQVYIGNG}^{104}\right)$, $75\left({ }^{149}\right.$ DGDALTLRTATN $\left.^{160}\right)$, and $76\left({ }^{151}\right.$ DALTLRTAT$\mathrm{NIW}^{162}$ ). The results suggest that ${ }^{331} \mathrm{NGNATPQLTKNA}^{342}$ is a common linear epitope of Cry $\mathrm{j} 1$. This peptide coincides with the N-terminal portion of the previously reported IgEreactive Cry j 1 fragment. ${ }^{9)}$ Since the reactivities of peptide $165\left({ }^{329}\right.$ VENGNATPQLTK $\left.^{340}\right)$ and $167\left({ }^{333}\right.$ NATPQLTK$\mathrm{NAGV}^{344}$ ) were weak, the core sequence ${ }^{332}$ GNAT-

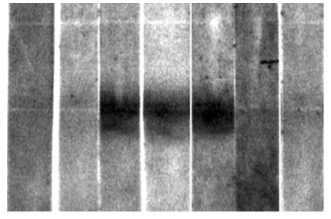

N G1 G2 G3 G4 G5 \#30

Pooled sera and serum nos.

Fig. 1. Immunoblot Analysis of Cry j 1 with Patients' Sera

Cry j 1 was electrophoresed in $8 \%$ polyacrylamide gel and subjected to immunoblotting with patients' sera. The bound IgE antibodies were detected with a chemiluminescence reagent. Lane $\mathrm{N}$, healthy donor; lanes $\mathrm{G} 1-\mathrm{G} 5$, pooled sera from patients; lane $\# 30$, serum from a single patient. Lane CBB, Cry $\mathrm{j} 1$ bands on the SDS-PAGE gel stained with Coomassie blue reagent.

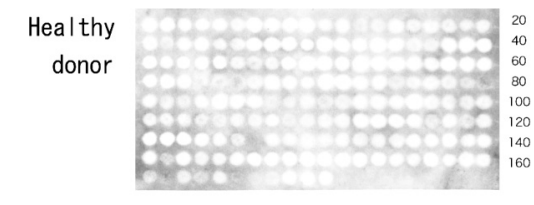

G2

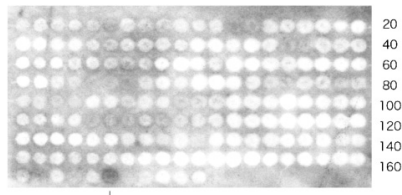

$\begin{array}{lll}166 & 47 \quad 52\end{array}$

G3

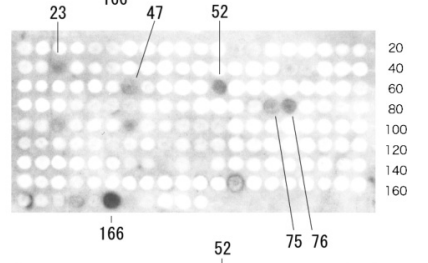

G4

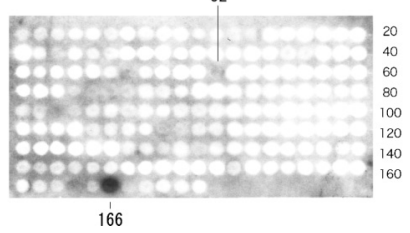

Fig. 2. Results of SPOTs Assay

The membrane with overlapping peptides was proved with pooled sera from cedar pollen allergy patients or a healthy donor.

PQLTKN $^{341}$ seemed to be important for IgE binding. Since the sequence ${ }^{103}$ NGGPCVFIKRVS $^{114}$ (peptide 52) were reactive with two of the three pooled sera, this may be a relatively common epitope. Other spots that reacted with pooled sera may also be IgE-epitopes.

The used sera were obtained from patients in Japan and United Stats, and many U.S. patients were also sensitive to Italian cypress and/or mountain cedar (Table 1), which contain the major allergens Cup s 1 and Jun a 1, respectively. The sequences of the allergens are similar to Cry j 1 ( $c a$. $80 \%$ homology), in particular, the corresponding sequences to $166\left({ }^{331} \mathrm{NGNATPQLTKNA}^{342}\right)$ were NGNLAPQLTKNA in Cup s 1 and NGNA APQLTKNA in Jun a 1 that are only two or one amino acids changes (the underlined amino acids). Since Italian cypress and mountain cedar are more general in United States than Japanese cedar, the patients in United States were possible to be sensitized primary with Cup s 1, Jun a 1 or other similar tree pollen allergens and the produced specific IgE antibodies were cross-reacted with Cry j 1 . 
Table 1. Serum Samples from Patients and the Grouping

\begin{tabular}{|c|c|c|c|}
\hline Group & Serum no. & $\begin{array}{c}\text { anti-Cry j } 1 \\
\text { IgE-ELISA } \\
(\text { OD450-570) }\end{array}$ & Other known sensitized allergens \\
\hline \multirow[t]{3}{*}{ G1 } & 1 & 1.268 & $\begin{array}{l}\text { Mites, baker's yeast, animals dander, foods, house dust, grass pollen, molds, alder, birch, mountain cedar, } \\
\text { Italian cypress }\end{array}$ \\
\hline & 2 & 1.000 & Alder, birch, beech, oak, ragweed \\
\hline & 3 & 0.868 & Pecan, Italian cypress, mountain cedar, elm \\
\hline \multirow[t]{3}{*}{ G2 } & 4 & 1.283 & Mites, animals dander, foods, venom \\
\hline & 5 & 1.654 & Foods, grass pollen, oak and other tree pollens, worm ragweed and other weeds \\
\hline & 6 & 0.770 & $\begin{array}{l}\text { Mites, foods, grass pollen, house dust, venom, cockroach, latex, molds, Italian cypress, beech } \\
\text { and other tree pollen, common ragweed and other weeds }\end{array}$ \\
\hline \multirow[t]{3}{*}{ G3 } & 7 & 1.307 & $\begin{array}{l}\text { Mites, animals dander and epithelium, foods, grass pollen, house dust, venom, cockroach, molds, birch, } \\
\text { Italian cypress, mountain cedar and other tree pollen, common ragweed and other weeds }\end{array}$ \\
\hline & 8 & 1.291 & $\begin{array}{l}\text { Animals dander, foods, grass pollen, house dust, venom, cotton seed, molds, birch, hazelnut, maple, } \\
\text { English plantain, mugwort }\end{array}$ \\
\hline & 9 & 0.648 & $\begin{array}{l}\text { House dust, animals dander, foods, malt, grass pollen, molds, birch, oak, mountain cedar, common ragweed } \\
\text { and other weeds }\end{array}$ \\
\hline \multirow[t]{10}{*}{ G4 } & 10 & 1.082 & \\
\hline & 11 & 0.577 & Mites \\
\hline & 12 & 0.581 & House dust, mites \\
\hline & 13 & 1.000 & House dust, mites \\
\hline & 14 & 0.846 & \\
\hline & 15 & 0.435 & House dust, mites \\
\hline & 16 & 0.509 & House dust, mites \\
\hline & 17 & 0.860 & Mites \\
\hline & 18 & 0.624 & \\
\hline & 19 & 0.672 & Mites \\
\hline \multirow[t]{11}{*}{ G5 } & 20 & 0.635 & Mites, foods \\
\hline & 21 & 0.967 & Mites \\
\hline & 22 & 0.647 & Mites \\
\hline & 23 & 0.641 & \\
\hline & 24 & 0.694 & \\
\hline & 25 & 2.096 & House dust, mites \\
\hline & 26 & 0.940 & House dust, mites, foods \\
\hline & 27 & 1.467 & Mites, animal dander \\
\hline & 28 & 0.698 & \\
\hline & 29 & 2.484 & \\
\hline & 30 & 1.494 & Mites, animals dander, weeds, molds, foods \\
\hline
\end{tabular}

Samples number $1-9$ were commercial sera and samples number 10-30 were sera from Japanese patients. A group contains equivalent amount of each serum.

Table 2. Peptide 166-ELISA of 10 Patients' Sera

\begin{tabular}{cc}
\hline \hline Serum no. & $\begin{array}{c}\text { Colorimetric } \\
\text { intensity } \\
\text { (OD450-570) }\end{array}$ \\
\hline 1 & $0.425^{*}$ \\
2 & $0.770^{*}$ \\
4 & 0.255 \\
5 & 0.294 \\
7 & 0.238 \\
8 & $0.456^{*}$ \\
10 & $0.415^{*}$ \\
13 & $0.406^{*}$ \\
20 & 0.207 \\
30 & $0.458^{*}$ \\
\hline
\end{tabular}

Average intensity of three control serum was 0.235 and SD was 0.066 . Average $+2 \times \mathrm{SD}=0.367(*$ : indicate peptide-ELISA positive) .

Peptide ELISA and Inhibition Peptide 166 and 52 were synthesized and used as coating antigens for peptide ELISA. Peptide 166 was reactive with six of the sera from 10 random patients (Table 2), however, the patients' sera did not react with peptide 52 (data not shown). The peptides were covalently bound to the plates with the N-terminal, free

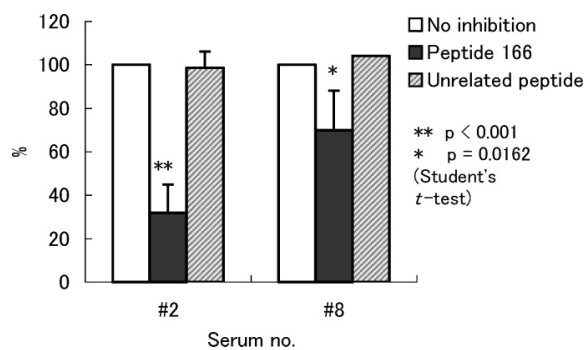

Fig. 3. Peptide 166-ELISA Inhibition

Sera from patients were preincubated with or without synthetic peptide $166(100 \mu \mathrm{M})$ or unrelated peptides $(100 \mu \mathrm{M})$. The serum IgE binding to peptide 166 was determined by peptide ELISA and expressed as \% of the control without inhibitors. Values are the mean of the 3 to 5 independent experiments.

amino group, or free thiol group in the peptide ELISA method, while C-terminal of each peptide is immobilized on the SPOTs membrane. Therefore, the IgE binding to the peptides in the two methods might not always be the same.

Two of the 166-reactive sera (\#2 and \#8) were applied to ELISA inhibition test. The binding of IgE in serum \#2 to peptide 166 was strongly inhibited by pre-incubation with $100 \mu \mathrm{m}$ peptide $166(68 \%, p<0.001$, Fig. 3$)$, and that in 
serum \#8 was also significantly inhibited $(30 \%, p=0.016)$. On the other hand, the binding of the serum IgE to the peptide 166-coated plate was not inhibited by the pre-incubation with $100 \mu \mathrm{M}$ unrelated peptide. Therefore, the binding of the IgE to the peptide plate was confirmed to be specific. Furthermore, The binding of other 166-reacted sera to the peptide plate had a tendency to be inhibited by peptide 166 .

The reported linear epitope NGNATPQLTKNAGVLTCSLSKR corresponds to amino acid residues $331-352$ and it was glycosylated with ${ }^{333}$ Asn. ${ }^{9)}$ However, inhibition assay revealed that the carbohydrates on Cry $\mathrm{j} 1$ were not always necessary for the binding of specific IgE in humans. ${ }^{11)}$

Though conformational epitopes of Cry j 1 play major roles in allergy, information of linear epitopes seems to be useful for the evaluation of cross-reactivity of $\mathrm{IgE}$ antibodies, and linear epitopes are suggested to be stable. Furthermore, information of B-cell linear epitopes is needed for future safety immunotherapy using allergenicity-decreased proteins. Our findings indicate that serum IgE in patients in Japan and the United States specifically recognizes the sequence ${ }^{331} \mathrm{NG}$ NATPQLTKNA $^{342}$, a linear epitope of Cry $\mathrm{j} 1$.

Acknowledgments This study was supported by a grant from the Ministry of Health, Labor and Welfare and by the Cooperative System for Supporting Priority Research of the
Japan Science and Technology Agency.

\section{REFERENCES}

1) Yasueda H., Yui Y., Shimizu T., Shida T., J. Allergy Clin. Immunol., 71, 77-86 (1983).

2) Taniai M., Ando S., Usui M., Kurimoto M., Sakaguchi M., Inouye S., Matuhasi T., FEBS Lett., 239, 329-332 (1988).

3) Fujimura T., Shigeta S., Kawamoto S., Aki T., Masubuchi M., Hayashi T., Yoshizato K., Ono K., Int. Arch. Allergy Immunol., 133, 125-135 (2004).

4) Tamura Y., Sasaki R., Inouye S., Kawaguchi J., Serizawa N., Toda M., Takemori T., Sakaguchi M., Int. Arch. Allergy Immunol., 123, 228235 (2000).

5) Kawashima T., Taniai M., Taniguchi Y., Usui M., Ando S., Kurimoto M., Matuhasi T., Int. Arch. Allergy Immunol., 98, 110-117 (1992).

6) Sakaguchi M., Hashimoto M., Nigi H., Yasueda H., Takahashi Y., Watanabe M., Nagoya T., Taniguchi Y., Kurimoto M., Inouye S., Immunology, 91, 161-166 (1997).

7) Duffort O. A., Carreira J., Nitti G., Polo F., Lombardero M., Mol. Immunol., 28, 301-309 (1991).

8) Polo F., Ayuso R., Carreira J., Mol. Immunol., 28, 169-175 (1991).

9) Taniai M., Kayano T., Takakura R., Yamamoto S., Usui M., Ando S., Kurimoto M., Panzani R., Matuhasi T., Mol. Immunol., 30, 183-189 (1993).

10) Frank R., Tetrahedron, 48, 9217—9232 (1992).

11) Ogawa H., Hijikata A., Amano M., Kojima K., Fukushima H., Ishizuka I., Kurihara Y., Matsumoto I., Glycoconj. J., 13, 555-566 (1996). 